\title{
Placental proteins and steroid hormones in the soluble fraction of human syncytiotrophoblast plasma membrane
}

\author{
P. M. Johnson, A. O. Ogbimi, M. J. Diver*, A. W. Thomson†, \\ R. D. Bremner $\dagger$ and C. H. W. Horne $\dagger$
}

Department of Immunology, University of Liverpool, P.O. Box 147, Liverpool L69 3BX;

*Department of Endocrine Pathology, Alder Hey Children's Hospital, Liverpool L12 2AP; and $\dagger$ Department of Pathology, University of Aberdeen, Aberdeen AB9 2ZD, U.K.

\begin{abstract}
Summary. Placental protein 5 (PP5), pregnancy-specific glycoprotein (SP1), pregnancy-associated $\alpha_{2}$-glycoprotein (SP3) and chorionic gonadotrophin could not be demonstrated in appreciable molar quantities in the soluble fraction from microvillous plasma membrane preparations isolated from the syncytiotrophoblast of full-term human placentae. However, progesterone, total oestriol and placental lactogen may have some association with this membrane.
\end{abstract}

\section{Introduction}

The syncytiotrophoblast plasma membrane in the human placenta represents the effective interface between mother and fetus, and the identification of membrane-associated components is of interest in the investigation of maternal-fetal immunological interactions in pregnancy (Johnson, Brown \& Faulk, 1980). Some human placental proteins and steroid hormones, such as chorionic gonadotrophin (hCG), placental lactogen (hPL), pregnancy-specific glycoprotein (SP1, PSG) and progesterone, have been reported to inhibit assays of lymphocyte reactivity in vitro (Contractor \& Davies, 1973; Cerni, Tatra \& Bohn, 1977; Clemens, Siiteri \& Stites, 1979). However, there have also been conflicting reports (Caldwell, Stites \& Fudenberg, 1975; Morse, 1976) and any immunoregulatory mechanism in vivo has yet to be clarified. Localization to the microvillous plasma membrane of the syncytiotrophoblast would greatly enhance the potential of any such components for an immunoregulatory role. We have therefore investigated whether various placental proteins and steroid hormones may be intimately associated with this membrane.

\section{Materials and Methods}

Microvillous plasma membranes were isolated from fresh syncytiotrophoblast of normal full-term human placentae and solubilized in $3 \mathrm{M}-\mathrm{KCl}$ or $1 \%$ sodium deoxycholate as previously described (Smith, Brush \& Luckett, 1974; Ogbimi, Johnson, Brown \& Fox, 1979). For $\mathrm{KCl}$-solubilized preparations, no dialysis procedures were employed; membranes solubilized in 3 $\mathrm{M}-\mathrm{KCl}$ were centrifuged at $1000 \mathrm{~g}$ for $10 \mathrm{~min}$, and the supernatant was taken and adjusted to 0.2 $\mathrm{M}-\mathrm{KCl}$ with distilled water. Protein antigenic and enzyme markers were used to confirm the trophoblastic source of material in the aqueous soluble fractions of sodium deoxycholate- and $\mathrm{KCl}$-solubilized membrane preparations, as described by Ogbimi et al. (1979). 
Placental lactogen concentration was determined by electroimmunoassay (Laurell, 1966) using monospecific rabbit antibody (Roche Products Ltd, Welwyn Garden City, Herts), and by radioimmunoassay using a kit from the Radiochemical Centre (Amersham, Bucks). hCG and the $\beta$-subunit of hCG ( $\beta$-hCG) were measured with radioimmunoassay kits from IRE, Belgium (Eurotope Services, Finchley, London). SP1 was measured by a double-antibody solid-phase radioimmunoassay (Towler, Horne, Jandial \& Chesworth, 1977), and pregnancy-associated $\alpha_{2}$-glycoprotein (SP3) was estimated by a modified electroimmunoassay (Thomson, Hunter, Cruickshank \& Horne, 1979). The placental protein PP5 was measured by a double-antibody solid-phase radioimmunoassay based on the method used by Chesworth (1977) and using rabbit anti-PP5 serum and purified PP5 (both kindly provided by Dr H. Bohn, Behringwerke AG, Marburg, Germany). Progesterone and total oestriol concentrations were determined by radioimmunoassay kits (progesterone: Behringwerke AG; total oestriol: Radiochemical Centre). Testosterone values were determined by an 'in-house' (M.J.D.) radioimmunoassay based on that first described by Furuyama, Mayes \& Nugent (1970) but using a more specific rabbit antiserum, to testosterone $7 \alpha-\mathrm{BSA}$, thus avoiding column purification of testosterone-containing fractions, as well as ${ }^{3} \mathrm{H}$-labelled testosterone (Radiochemical Centre) and dextran-coated charcoal to separate the bound and free fractions. SP3 and testosterone were included in this study as a pregnancy-associated protein and steroid hormone, respectively, which are thought not to be significantly synthesized in human trophoblast (Baulieu, Wallace \& Lieberman, 1963; Horne, Bohn \& Towler, 1976a).

\section{Results and Discussion}

As shown in Table 1, hCG, $\beta$-hCG, PP5, SP1 and SP3 were each not detected in appreciable amounts in the soluble fraction from trophoblast plasma membrane preparations. The figures for each protein represent values of $<0.04 \%$ of the total trophoblast membrane-associated protein, and may be considered to be below the level of significant detection when related to the possibility of trace contamination of trophoblast microvilli preparations with cytoplasmic elements. It would appear from these results that a glycoprotein identified by gel electrophoretic analysis as a major trophoblast membrane-associated protein component of molecular weight 36500 (Ogbimi et al., 1979) is not PP5, a placental glycoprotein of molecular weight 36600 (Bohn \& Winckler, 1977). Immunohistological studies have suggested that SP1 and hCG may be associated with human syncytiotrophoblast plasma membrane (Naughton et al., 1975; Horne, Towler, Pugh-Humphreys, Thomson \& Bohn, 1976b). This apparent localization could therefore reflect trophoblastic protein production rather than a specific membrane retention effect, although different sensitivities of experimental approach may also be considered; for example, SP1 membrane localization was shown by immunohistology on first-trimester placental tissue (Horne et al., 1976b) rather than full-term tissues as used in this quantitative study. In contrast, hPL was detected in the soluble fraction from isolated trophoblast microvilli at a higher molar concentration than were the other placental proteins (Table 1), although the hPL values still represent less than $0.25 \%$ of the total trophoblast membrane-associated protein. These molar values are much lower than those calculated for some other trophoblast membrane-associated components, such as sialic acid (A. O. Ogbimi \& P. M. Johnson, unpublished). However, unlike SP1, there appears to be an enrichment of hPL on trophoblast plasma membrane preparations compared with figures for retroplacental serum (Klopper \& Hughes, 1978) when values are expressed as $\mu \mathrm{g} \mathrm{hPL/mg} \mathrm{total} \mathrm{protein} \mathrm{in} \mathrm{solubilized} \mathrm{membrane} \mathrm{preparations} \mathrm{or} \mathrm{in} \mathrm{serum,}$ respectively. Clearly, it would be of interest to study trophoblast plasma membrane preparations isolated from first-trimester placentae, although preliminary investigations have suggested that it is difficult to achieve membrane preparations comparable in purity to those from term placentae. 
Table 1. Pregnancy proteins and steroid hormones in the soluble fraction from isolated microvillous plasma membrane preparations from syncytiotrophoblast of women at full-term

\begin{tabular}{lcc}
\hline \multirow{2}{*}{$\begin{array}{l}\text { Pregnancy protein or } \\
\text { steroid hormone }\end{array}$} & \multicolumn{2}{c}{ Concentration range* } \\
\cline { 2 - 3 } & $\mu \mathrm{g} / \mathrm{mg}$ total membrane protein $\dagger$ & pmol/mg total membrane protein $\dagger$ \\
\hline hPL & $1-2 \cdot 5$ & $45-110$ \\
hCG & $0 \cdot 02-0.04$ & $0.5-1$ \\
$\beta$-hCG & $0.01-0.02$ & $0.5-1$ \\
SP1 & $0.08-0.2$ & $0.8-2$ \\
SP3 & $<0.4$ & $<0 \cdot 1$ \\
PP5 & $0.02-0.17$ & $0.5-5$ \\
Progesterone & $4 \cdot 2-5.3 \times 10^{-3}$ & $13-17$ \\
Oestriol & $<7 \times 10^{-3}$ & $<24$ \\
Testosterone & $3-7 \times 10^{-6}$ & $7-17 \times 10^{-3}$ \\
\hline
\end{tabular}

* Range for estimations for 3-5 separate membrane preparations.

$\dagger$ Total protein determined by the method of Lowry et al. (1951).

Quantitative estimations of hPL and SP1 after sodium deoxycholate solubilization of trophoblast plasma membranes were generally lower within the ranges obtained (Table 1) than for those after $\mathrm{KCl}$ solubilization, possibly indicating some loss of antigenicity following sodium deoxycholate treatment. However, pregnancy sera treated similarly with sodium deoxycholate gave SP1 and hPL values that were never lower than $80 \%$ of the values obtained for untreated sera, whereas pregnancy sera treated with $3 \mathrm{M}-\mathrm{KCl}$ gave values identical to those obtained for untreated sera.

Progesterone and total oestriol were present in appreciable molar concentrations in the soluble fraction from trophoblast plasma membrane preparations (Table 1). The progesterone level was approximately 2 -fold lower than that reported by Smith \& Brush (1978), possibly reflecting losses during the membrane solubilization procedure. However, our values are not significantly increased compared with figures for maternal peripheral venous serum or retroplacental serum (Hobson, 1971; Klopper \& Hughes, 1978) when expressed as ng steroid/mg total protein in solubilized membrane preparations or in serum, respectively. Nevertheless, since such calculations are relating the steroid content to two quite separate protein populations, it is still uncertain whether a local concentration of sex hormones (demonstrable here associated with washed trophoblast microvilli preparations and removable by membrane-disruptive agents) is sufficient to be active in a local immunoregulatory role in maternal-fetal interactions as suggested by Clemens et al. (1979).

R.D.B. is in receipt of an M.R.C. fellowship, and we thank Miss R. G. Glover for excellent technical assistance.

\section{References}

Baulieu, E.-E., Wallace, E. \& Lieberman, S. (1963) The conversion in vitro of $\Delta^{5}$-androstene-3 $\beta$-17 $\beta$-diol-

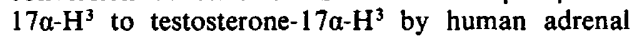
and placental tissue. J. biol. Chem. 238, 1316-1319.

Bohn, H. \& Winckler, W. (1977) Isolation and characterization of placenta-protein PP5. Arch. Gynäk. 223, 179-186.

Caldwell, J.L., Stites, D.P. \& Fudenberg, H.H. (1975) Human chorionic gonadotrophin: effects of crude and purified preparations on lymphocyte responses to phytohaemagglutinin and allogeneic stimulation. $J$. Immun. 115, 1249-1253.

Cerni, C., Tatra, G. \& Bohn, H. (1977) Immunosuppression by human placental lactogen (hPL) and pregnancy-specific $\beta_{1}$-glycoprotein (SP1). Arch. Gynäk. 223, 1-7.

Chesworth, J.M. (1977) Radioimmunoassay of ovine LH and ovine prolactin using polymerised second antisera. Analyt. Biochem. 80, 31-40.

Clemens, L.E., Sitteri, P.K. \& Stites, D.P. (1979) 
Mechanism of immunosuppression of progesterone on maternal lymphocyte activation during pregnancy. J. Immun. 122, 1978-1985.

Contractor, S.F. \& Davies, H. (1973) Effects of HCS and HCG on phytohaemagglutinin-induced lymphocyte transformation. Nature, New Biol. 243, 284285.

Furuyama, S., Mayes, D.M. \& Nugent, C.A. (1970) A radioimmunoassay for plasma testosterone. Steroids 16, 415-428.

Hobson, B.M. (1971) Production of gonadotrophin, oestrogens and progesterone by the primate placenta. Adv. Reprod. Physiol. 5, 67-102.

Horne, C.H.W., Bohn, H. \& Towler, C.M. (1976a) Pregnancy-associated $\alpha_{2}$-glycoprotein. In Plasma Hormone Assays in Evaluation of Foetal Well-being, pp. 136-146. Ed. A Klopper. Churchill Livingstone, London.

Horne, C.H.W., Towler, C.M., Pugh-Humphreys, R.G.P., Thomson, A.W. \& Bohn, H. (1976b) Pregnancy-specific $\beta_{1}$-glycoprotein - a product of syncytiotrophoblast. Experientia 32, 1197-1199.

Johnson, P.M., Brown, P.J. \& Faulk, W.P. (1980) Immunobiological aspects of the human placenta. In Oxford Reviews in Reproductive Biology and Endocrinology, Vol. 2, Ed. C.A. Finn. Oxford University Press, London. (in press).

Klopper, A. \& Hughes, G. (1978) Placental secretion of oestrogens and protein hormones. Arch. Gynäk. 225, 171-177.

Laurell, C.B. (1966) Quantitative estimation of proteins by electrophoresis in agarose gel containing antibodies. Analyt. Biochem. 15, 45-52.
Lowry, O.H., Rosebrough, H.J., Farr, A.L. \& Randall, R.J. (1951) Protein measurement with the Folin phenol reagent. J. biol. Chem. 193, 265-275.

Morse, J.H. (1976) The effect of human chorionic gonadotrophin and placental lactogen on lymphocyte transformation in vitro. Scand. J. Immun. 5, 779-787.

Naughton, M.A., Merril, D.A., McManus, L.M., Fink, L.M., Berman, F., White, M.J. \& Martinez-Hernandez, A. (1975) Localization of the $\beta$-chain of human chorionic gonadotrophin in human tumour cells and placental cells. Cancer Res. 35, 1887-1890.

Ogbimi, A.O., Johnson, P.M., Brown, P.J. \& Fox, H. (1979) Characterisation of the soluble fraction of human syncytiotrophoblast microvillous plasma membrane-associated proteins. $J$. Reprod. Immunol. 1, 127-140.

Smith, N.C. \& Brush, M.G. (1978) Preparation and characterisation of human syncytiotrophoblast plasma membrane. Med. Biol. 56, 272-276.

Smith, N.C., Brush, M.G. \& Luckett, S. (1974) Preparation of human placental villous surface membranes. Nature, Lond. 252, 302-303.

Thomson, A.W., Hunter, C.B.J., Cruickshank, N. \& Horne, C.H.W. (1979) Study of pregnancyassociated alpha ${ }_{2}$-glycoprotein in relation to populations of human blood leucocytes. Int. Arch. Allergy appl. Immun. 58, 251-259.

Towler, C.M., Horne, C.H.W., Jandial, V. \& Chesworth, J.M. (1977) A simple sensitive radioimmunoassay for pregnancy-specific $\beta_{1}$-glycoprotein. Br.J. Obstet. Gynaec. 84, 580-584.

Received 14 November 1979 